\title{
Technical Skill and Professional Practices of Tailors and Seamstress in Abeokuta Metropolis
}

\author{
${ }^{1}$ Sunday Roberts. Ogunduyile (Ph.D), ${ }^{2}$ David Olajde Makinde (Ph.D), \\ ${ }^{3}$ Peter Oladipo Olowookere, ${ }^{4}$ Olugbenga Benjamin Emidun \\ ${ }^{I}$ DepartmentIndustrial Design Federal University of Technology, Akure, Nigeria \\ ${ }^{2}$ Department of Fine and Applied Arts Obafemi Awolowo University, Ile Ife, Nigeria \\ ${ }^{3}$ Department of Fine and Applied Arts, Federal College of Education, Osiele, Abeokuta, Ogun State. \\ ${ }^{4}$ Department of Industrial Design, Federal University of Technology, Akure, Nigeria
}

\begin{abstract}
Technical skill is important in the study of design and tailoring styles. This study assesses the technical skill of tailor and seamstress in Abeokuta, Ogun state Nigeria with objectives of examining consumers' opinion on sewing skill, investigation of tailoring facilities and also investigation level of level of interest of the youth in the vocation. The study adopted survey design. The instrument used was structured questionnaire which was used to elicit data from respondents. The research population comprised of all registered tailors, seamstresses and end users of tailored products in Abeokuta, Ogun State. Data collected were analyzed with both descriptive and inferential statistic using the software Statistical Package for Social Sciences, SPSS version 11.0. Results showed through the statement of objectives, research questions and hypotheses that both tailor and seamstresses are skillful and that tailors in Abeokuta have adequate facilities to work with.
\end{abstract}

Keywords: Technical skill, tailor, seamstresses, consumers, sewing skill

\section{INTRODUCTION}

Technical skills and professionalism are pertinent in the practice of industrial design. It is perhaps, impossible to conceive of a modern nation without relying upon the characteristics of professional behaviour of Industrial Designers, artisans and craftsmen as indispensable to community growth and development (Swindells, Atkinson and Sibley, 2001). Ogunduyile, Kayode and Ojo, (2008) are in support of this, noting that it is impossible to conceive a socio-economically viable society without reckoning on the economic contributions of people who are into the practice of the skills of their vocations or trades. Akinlami (1999) notes that man, in history has distinguished himself from other creatures by being skillfully creative and by inventing tools to suit his comfort. Comfort in this sense embraces food, good health, and privacy by the way of shelter, clothing, and protection among other things. If all of these cease, Diogu (2000) is of the opinion that there will be little or no comfort.

Textiles and clothing are noted in Ajayi (2002) as dynamic social and economic activities, the technical skills of tailors and seamstresses in the provision of comfort parametres cannot be over-emphasized in the world of fashion and design. For instance, Scribe (2009) points out that although fashions are created by designers, the skilled tailors and seamstresses in one's community are the ones with the ultimate task of following and assembling the final product for peoples' uses. The gender dimension of tailoring and seam stressing is noted in the explanations of Crowston (2000) and Scribe (2009) that tailor refers to male in the tailoring and sewing guild while seamstress refers to their female counterpart. However, tailoring skills cannot be separated from the other technical and vocational skills which have been considered as important to creativity and socio-economic development of mankind. It has its pedigree as an ancient professional practice but has moved over the years into the fashion vogues. Fashion is a profile of tailoring skills which is resurgent and cyclic in styles and skills. Akinbogun (2000) expresses that man in the quest for aesthetic satisfaction will always discover new skills for new life in an old world and thus man's aesthetic appreciation will continue to swing back and forth like pendulum. Though, it has been said that tailoring and fashion skills originated from antiquity and represent a popular value of mankind, the practices of tailoring and fashion skills transform as values change in society (Ogunduyile, 1999). The earliest appearance of design skills was evident in the early man's paraphernalia and ego traits for comfort, respect, dignity and protection. For example, when man fell from the Garden of Eden and discovered that he was naked, there came a spontaneous need for a measure to be put in place to cover the private parts with the then available material which were leaves (Holy Bible, Kings James version 2004,Genesis 3:7). Then, the process of cutting leaves, measuring it to cut sizes and putting together the cut pieces for covering the body can be taken as the exactitude of the definition of tailoring. In Microsoft Encarta (2008) and 
Boyer (2009), tailoring is a style or a way in which clothes are measured, cut and sewn into wears for covering and for other utilitarian purposes. The Industrial Revolution of the 1750s to 1850s has advanced a good cause for product and services delivery (Haruna, 2001). The crude beginning of tailors and their skills as manual crafts have now been significantly perfected and blossom into a well recognize profession with appropriate technology and merchandizing tools.

Though tailors seem to abound almost everywhere due to the inevitability of clothing to the contemporary man, interest in tailoring skill acquisition needs to be assessed as it appears that the present generation of youths are showing decreasing interest in learning the trade. In this vein, Anidugbe (2003), Ogunduyile, Kayode and Ojo (2008) posit that decline of interest in vocation business; wrong priorities and notion are the present banes of skill acquisition in professional practice generally. All of these parameters among others will have to be considered in order to arrive at a reliable research position concerning the true situation about tailors' technical skills and tailoring practice in the Abeokuta metropolis.

\section{STATEMENT OF THE PROBLEM}

In time past, growing appreciation for handmade African fabrics, both as pieces of art and as materials for "high-fashion" clothing, bode well for the survival of traditional skills (Khaminwa, 2010). Today, there is dwindling decrease in the numbers of youths showing interest in tailoring. However, the skill of those in the field and the few ones coming into the trade can not be considered as improving due to the advancement in technology and more enriched clothing culture of Nigerians.

It is a truism that the Nigerian youths over the years, have not shown much interest in enrolling as tailoring apprentices. This might be due to the fact that other fast money making opportunities such as in commercial motorcycle business (Okada) and in transportation are beginning to draw more of the youth's attention. Also, Pilot studies of the research indicated that the patronage of foreign ready-to-wear clothing by Nigerians was necessitated by the perfection of their sewing skills which Nigerian tailors have been unable to match. The perfection in sewing of these imported clothing is probably due to the availability of adequate technology with dexterity and expertise of tailors employed in the fashion industry.

Generally, tailors have been accorded low status because most of them could hardly provide adequately for their families. The procurement of modem working facilities are also elusive to them due to inadequate funds and inadequate educational background, the resultant effects of these inadequacies is that most tailors could not give adequate satisfaction to their customers in terms of perfection in styles, elegance and meeting deadlines. It is pertinent to assess the professional practice of tailors with a view to bringing encouragement to the younger ones who might be interested in the trade.

\section{Research Questions}

1. Do tailors in Abeokuta have the necessary educational background, skills and competence to meet with demands of modem times?

2. To what extent are the youths in Abeokuta showing interest in learning tailoring?

3. Do tailors in Abeokuta meet customers' demand in terms of styles and precision of delivery time?

\section{Aim and Objectives}

Aim of the study

The aim of this study is to undertake an assessment of professional practice of tailors in Abeokuta metropolis with a view of encouraging the younger ones who might be interested in the trade.

\section{Objectives of the Study}

The specific objectives of the study are to:

1. identify the professional tailors and seamstresses in Abeokuta;

2. investigate the quality of the tailoring facilities in use with a view to suggest ways to improve them;

3. examine consumer's opinion on sewing skills of both tailors and seamstresses.

\section{Research Hypotheses}

1. There is no significant difference in the professional skill proficiency exhibited by tailors and seamstresses in Abeokuta.

2. There is no significant relationship between the quality of tailoring facilities and the technical output of tailors in Abeokuta.

\section{The Scope of the Study}

The scope of the study revolves round technical skills and professional practice oftailorsand seamstresses .The study is limited to Abeokuta metropolis in Ogun state. Abeokuta was chosen being an ancient town known all over the world as a tourist inaction for indigenous fabrics which are the raw materials for tailors. 


\section{Justification of the Study}

The research has attempted to establish that there are various studies on textiles and tailoring that have presented in empirical and theoretical forms. At the same time, it has also been discovered through literature reviews and internet searches that none of these studies dwell on assessment of professional practice of tailors, or any appreciable inference made on the artistic skills of embellishments on clothing. This aspect remain a strong focus of the study. For instance, while the study is looking at assessment of tailoring skills and professional practice in Abeokuta metropolis, Ogun State, Nigeria, Hester and McDowell (1987) is study that centered on tailoring economics. In the study, It is noted that employment in the textile and clothing industries have declined dramatically due to increase imports and lack of marketing orientation. The study empirically confirms that this decline has been especially devastating to small firms like the tailoring outfits.

Azuma and Fermie (2003) is another study that is entirely different from the present study in that it is about investigation on the multiplicity of Japenese in-vogue fashion styles. The focus really is not on how those fashion styles were cut and sewn but on standardization and low-cost advantage of in-vogue fashion styles. The study argues that the emergence of global fashion has transformed the way fashion is perceived in the contemporary world. It considers the phenomenon of fashion in the globalized world and the role of virtual networks in intrinsic fashion design along with cultural, ethical, economic and environmental parameters. Also in Trautman (2006) is on a concise aspect of tailoring that looks at the reality of the profession. It used simple descriptive statistics to analyze how is socio-economically stratified.

From findings, the studies mentioned above focus strongly on what can broadly be seen as textile material studies, globalized fashion concepts, clothing industry, and textile merchandizing. These studies do not mention the skill rendition of tailors nor dwell, by any appreciable inference, on tailors and seamstresses professional practice. Nevertheless, the research intends to add to the frontiers of knowledge by looking at the particular area of technical skill and professional outputs of tailors and seamstresses in which a gap has been discovered to exists, especially as it relates to Abeokuta metropolis, Ogun State.

The study on an assessment of professional practice of tailors is an innovation as it brings together analysis of national discourses cut and sew fabrics whose issues have not been given consideration. It is believed that this research can be helpful to the nation building by promoting small scale enterprises and establishments which outputs directly affects the nation's economy in term of gross domestic product. The researcher is particularly committed to sharing the result of the analysis with government and relevant nongovernmental agencies in order to provide information that can foster formulation of policy an enhance local resources management

\section{The Scope of the Study}

The scope of the study revolves round technical skills and professional practice of tailors and seamstresses. The study is limited to Abeokuta metropolis in Ogun State. Abeokuta was chosen being an ancient town known all over the world as a tourist attraction for indigenous fabrics which are the raw material for tailors.

The study examines how fabrics are sourced, cut and sewn by tailors in the styles. The skills of cutting and sewn are very important in this regard. The study mentions different categories of practitioners) males, females, young, old), different locations and the working conditions of tailoring in Abeokuta. It is observed that tailoring, seam stressing and fashion designing are synonymous; the study then identifies the present design trends in Abeokuta metropolis and the relatedness of the terms.

\section{Operational/Conceptual Definition of Tailors, Seamstresses and Fashion Designers}

Many issues that have been discussed on the conflicting roles of tailors, seamstresses and fashion designers are based on remote interpretations and misrepresentation of functions. Besides, Crowston (2000) opines that many of the negative inference as well have turned out to broaden the horizon of the examination of the technical roles ascribed to them.

Tailor in a real sense, is the name given to a man who makes men's clothes, while a seamstress is usually a woman making women's clothes (Wikipedia, 2008). A seamstress is considered as a join-man who performs alterations or precise sewing for big jobs. Tailors are usually into design and construction of clothing suits, gowns, dresses and jeans.

Discrimination in gender roles and performing skills of the tailors and seamstress make worse their controversial functions. For example, a tailor (usually man) can also perform the roles of seamstress. This implies that a man-tailor can also stitch, sew, join, and use machine to make a complete set of woman's garment, but he cannot be called a seamstress.

In the same vein, a seamstress who is skillful in making for both males and females cannot be called a tailor. No wonder the notion of who is and what a tailor does becomes controversial in the academic circle. In 
order not to confuse the reading audience, this project prefers to use the terms tailors and seamstress in relationship to their separate roles in Abeokuta metropolis.

In recent times, Nigerian tailors and seamstress are assuming to change their trade name to fashion designers as those meeting the technical requirements of the global world in order to re-awaken the hope of their customers. The fact that a tailor or seamstress is an accessory to fashion designs process cannot be disputed. A tailor is not a fashion designer by practice and dictionary meaning. Fashion design involves the designing and illustration of apparels in vogue to be sold to designers who in turn employ tailors and seamstress for the interpretation of design styles into garments.

A fashion designer may not necessarily be a tailor or a seamstress who can attract client to his shop. Fashion designers usually associate with apparel manufactures, creating designs of men, women, and children for mass distribution in markets.

\section{Review of Related Literature}

Literature reviews serves several important purpose in research. Although Aluko (1999) upholds the opinion that researchers have followed a logical sequence of events since the $18^{\text {th }}$ century, it is clear that yarning gaps have existed in what is known about each event. These gaps should be filled if research would be worth going into.Similarly,Nworgu (1991) remarks that the world in which we live is full of many unknown and undiscovered facts, therefore, literature search for both theoretical and empirical knowledge will be of importance. Keeping up with the past and recent development about what other researchers have done or are doing in the area of tailoring, textile and fashion designing is a product of necessity. The literature review for this study give credit those who, laid the groundwork for the study, demonstrated the researcher's knowledge of the research problems and also demonstrated adequate understanding of the theoretical and research issues related to the study objectives, research question and the hypotheses.

This section provides a link for the major gap in literature and in the entire body of knowledge. Precisely the review of literature for this study entails the theoretical and empirical works of scholars in the area of tailoring, sewing, fashion and textile design, clothing assemblage, education and apprenticeship as well as application of newest technologies and more avant-garde trends in the textiles professional skills.

\section{Origin of Tailoring/Seamstressing in Nigeria}

There are little or no written records of the origin of tailoring in Nigeria, but the story of its process and development is not different from other African Countries.The study of clothing and tailoring in African Countries where garments were made of leather and other non-fabrics materials derives meaning from the environment in which it is worn. This involves the different social groups and to an extent each group has its own belief and behaviours and as a result, styles of clothing for each sub-culture exist (Steel, 2002).

It is noted in Ojo (2002) that the Yoruba traded with Arabs. In the process of trading, the Yoruba derived both the benefits of livelihood and occupational satisfaction in dyeing, cotton growing, spinning and weaving and fabric embellishment. The 1750-1850 Industrial Revolution in Europe brought many inventions which included sewing machines. Its uses spread and extended to the coast of Africa where tailors and drapers were trained specifically in the designing of clothes for hunting, working, farming and manual labours (Ojo, 1997). Negri (1976) cited in Ojo (2000) writes on how a wide range of Nigerian gown and clothes were influenced by the Arabs, Tuaregs, Nubians and the Portuguese. Specifically, Negri further alluded that the Portuguese women's headgears and accessories had so much fascination designs that inspired Yoruba traders who returned to their home base (Ile Ife) to establish their shops. By the middle of the nineteenth century, Negri confirmed that Kano had already mastered the art of cloth weaving and dyeing and was famous in it. As years rolled by, Nigerian clothes specifically that of the Yoruba and Hausa began to carry heavy embroideries.

Oguntuyi (1979) and Ojo (2000) note that Yoruba costumes such as Dandogo, Gbariye and Sokotobegan to wear new looks. Importation and uses of sewing and fitting machines have greatly aided their new innovations. The basic Yoruba men's agbadaand sokoto or women's buba and iro can now be sewn within few hours.

\section{The History of Tailoring in Abeokuta}

Biobaku (1991) notes that tailoring in Abeokuta came as a result of the missionaries who were sent to preach the Chritian Gospel in Nigeria where majority of the missionaries settled at Abeokuta, as they were preaching the gospel they introduced other vocational education to the members of the congregation. Such vocation includes tailoring, carpentry, bricklaying and weaving so that they can be helpful to the church. Tailors are to sew the uniform for the choirs, teacher and clergy men, carpenters and bricklayers are to see to the construction and maintenance of the church building. The aftermath of these trainings encourages many participants to establish private shops for their business. 
Ojo (2000) notes that tailoring in Abeokuta could be linked to the trade between the Yoruba's and Arab's, which allowed Yoruba to derive this livelihood from dyeing, spinning, weaving, and fabric embellishment. The industrial revolution in Europe which brought about the invention of sewing machines to replace the use of hand to sew has been acknowledged. The uses of these machines extended to the Coast of Africa where tailors and drapers were trained to design clothes for hunting, working, farming and manual labours.

Ojo (2002) and (2001) also corroborate the submission of Biobaku (1991) that the influence of the Second World War (WWII) brought about an oscillation growth in the development of tailoring in South Western Nigeria. Some of the world war returnees and absentees were exposed to repairs, cuttings, sewing and the general manufacture of fighting uniforms at war camps with sewing machines that they never saw before. Their arrival from the war fronts coincided with the use of sewing machines which some of them could use without undergoing another form of training. The spread of tailoring skills from Abeokuta to the neighbouring province moved like wide fire. Apprentices became multiplied and the desire to own a sewing machine became a matter of chance.

Trends and Methods of Tailoring and Sewing in Abeokuta

Biobaku, (1991) explains that tailors in Abeokuta could be classified under two subheading:-

1. Academic professionals

2. Professionals

Academic professionals

These are the set of tailors, trained from fashion schools, which involve entry qualifications and has mode of examination and at the end of the course, which can be one or two years, a certificate is awarded. Example of such is "Labax" fashion outfit- a graduate from university of Agriculture Abeokuta, who has an outfit along MoshoodAbiola way, Abeokuta admits students who have completed secondary education, taking entrance examination into the design school and admitted for two years and at the end of their training, Diploma certificate were given or awarded to them.

\section{Professionals}

These are set of people who acquire the knowledge and skill through non-formal or informal setting,

\section{Informally Trained}

These are the set of people who learn through apprenticeship from friends or relatives, it does not have time limit and certificate will also be awarded at the end of the training, and these set of a people can still acquire more knowledge from the professionals who do not require any basic qualification, before being admitted into the workshop, whereby learners were to show their competence and proficiency through the display of some products.

\section{Data presentation}

This section presents the data collected for the study and the discussion of the findings based on the research questions, objectives of the study and hypotheses generated for the study. While hypotheses 1 and 2 were tested with t-test and Pearson Moment Product Correlation respectively, similarly, hypothesis 3 was tested with the aid of chi-square. All hypotheses were tested at 0.05 level of significance. The result are presented below

Tailors Education and Professional Competence in Abeokuta

The responses of both the tailors and end-users of tailored products were scored using frequency counts and the percentage was then calculated. The result is as presented below:

Table 1: Educational Background and Professional Competence of Tailors in Abeokuta

\begin{tabular}{|l|l|l|l|l|l|}
\hline & UN & SD & D & A & SA \\
\hline Vb 34 & $40(7.2 \%)$ & $67(12.0 \%)$ & $169(30.3 \%)$ & $139(24.9 \%)$ & $143(25.6 \%)$ \\
\hline Vb 35 & $28(5.0 \%)$ & $60(10.8 \%)$ & $76(13.6 \%)$ & $146(26.2 \%)$ & $248(44.4 \%)$ \\
\hline Vb 36 & $20(3.6 \%)$ & $901(6.1 \%)$ & $176(31.5 \%)$ & $100(17.9 \%)$ & $172(30.8 \%)$ \\
\hline Vb 37 & $39(7.0 \%)$ & $77(13.8 \%)$ & $77(13.8 \%)$ & $167(29.9 \%)$ & $198(35.5 \%)$ \\
\hline Vb 38 & $36(6.5 \%)$ & $44(7.9 \%)$ & $76(13.6 \%)$ & $81(14.5 \%)$ & $321(57.5 \%)$ \\
\hline Average & $\mathbf{3 7}$ & $\mathbf{6 8}$ & $\mathbf{1 1 5}$ & $\mathbf{1 2 7}$ & $\mathbf{2 1 6}$ \\
\hline
\end{tabular}

Source: Authors' fieldwork, 2016 
Variables Definitions

Vb34 = Reading and writing is not necessary to become a tailor/seamstress.

$\mathrm{Vb} 35$ = Formal schooling is off no use in sewing and tailoring.

$\mathrm{Vb} 36=$ Educated tailors and seamstresses get more sales than the illiterate tailors/ seamstress.

Vb 37 = Tailors in Abeokuta do not have necessary educational background, skills and competence to meet with the demand of modem times.

$\mathrm{Vb} 38=$ Tailors in Abeokuta are more educated than the seamstresses

Table 1 presents data on the educational background of tailors in Abeokuta, in which case. 282 (50.2\%) respondents out of 558 agreed that reading and writing are not anry to become a tailor or seamstresses. The table also reveals that $236(42.3 \%)$ agreed, while $40(7.2 \%)$ were undecided in their response. On the relevance of formal schooling of tailoring, $394(70.6 \%)$ agreed that formal schooling is of no use in sewing/ tailoring. 136 $(24.4 \%)$ disagreed and $28(5.0 \%)$ were undecided. The question of whether educatedtailors/seamstresses get more sales than illiterate tailors/ seamstress, $272(48 \%)$ agreed that educated tailors/seamstresses get more sales than the illiterate, $266(47.6 \%)$ disagreed, 20 (3.6\%) were undecided in their response. In asking whether tailors in Abeokuta have necessary educational background and competence to meet with the demand of modern times, it was discovered that $365(65.4 \%)$ agreed that tailors in Abeokuta do not have necessary educational background and competence to meet with the demand of modem times, $154(27.6 \%)$ respondents disagreed, while $39(7.0 \%)$ were undecided in their response. Similarly, $402(72 \%)$ respondent agreed that tailors in Abeokuta are more educated than seamstresses, 120 (21.5\%) disagreed, while $36(6.5 \%)$ were undecided.

Table 1 indicates the frequency percentage of the responses of respondents. The research question here deals with the educational background, skill and professional competence of tailors in Abeokuta. The result of this study is that tailors and seamstresses in Abeokuta generally do not have adequate educational background of the modem times. This result is at variance with the result in Offaiong (2009) which maintains that tremendous innovations and contemporary changes are being experienced daily in the tailoring and fashion trades. Offaiong further notes that most tailors and fashion designers are formally trained or apprenticed. However, it is noted that the sharp contrast in the results of Offaiong's study and this study is as a result of difference in study area characteristics; this study was earned out in Abeokuta while Offaiong's study was earned out in London. It is also observed that, although the two studies samples tailors and seamstresses, the number of samples taken by Offaiong was 1,500 while this study took 558 samples.

\section{Youth Interest in Tailoring Vocation}

The frequency count and percentage of the responses of both the tailor and end users to the issue of youth interested in tailoring were calculated and the result presented in table 2 below

Table 2: Interest of the Abeokuta youths in

\begin{tabular}{|l|l|l|l|l|l|}
\hline & UN & SD & D & A & SA \\
\hline Vb 39 & $26(4.7 \%)$ & $38(6.8 \%)$ & $127(22.8 \%)$ & $183(32.8 \%)$ & $184(33.0 \%)$ \\
\hline Vb 40 & $29(5.2 \%)$ & $66(11.8 \%)$ & $124(22.2 \%)$ & $135(24.2 \%)$ & $204(36.6 \%)$ \\
\hline Vb 41 & $53(5.9 \%)$ & $106(19.0 \%)$ & $108(19.4 \%)$ & $101(18.1 \%)$ & $190(34.1 \%)$ \\
\hline Vb 42 & $57910.3 \%)$ & $106(19.0 \%)$ & $106(19.0 \%)$ & $100(17.9 \%)$ & $189(33.9 \%)$ \\
\hline Average & $\mathbf{4 1}$ & $\mathbf{7 9}$ & $\mathbf{1 1 6}$ & $\mathbf{1 2 9}$ & $\mathbf{1 9 0}$ \\
\hline
\end{tabular}

Source: Authors' fieldwork, 2016

Key:- UN= Undecided, SD = Strongly Disagree, $\mathrm{D}=$ Disagree, $\mathrm{A}=$ Agree, $\mathrm{SA}=$ Strongly Agree.

Table 2 presents the responses of respondents on the extent to which youths in Abeokuta show interest in tailoring business.Out of 558 respondents, $367(65.8 \%)$ agreed that the youths in Abeokuta have little interest in tailoring and sewing, $165(29.6 \%)$ disagreed, while $26(4.7 \%)$ were undecided in their response. On question whether tailoring trade in Abeokuta consists of more youths than the elders, $339(60.8 \%)$ agreed that tailoring trade in Abeokuta consists of more youths than the elders, 190 (34\%) disagreed in their response, while $29(5.2 \%)$ were undecided. Similarly, $291(52.2 \%)$ agreed that the interest of youths in tailoring is decreasing, $214(37.5 \%)$ disagreed, while $53(9.5 \%)$ were undecided. The results also shows that $289(57.8 \%)$ agreed that female youths have more interest in sewing than their male counterparts, $212(38 \%)$ respondents disagreed while 57(10.3\%) were undecided.

Table 2 is about the interest of the youths of Abeokuta in tailoring, which generally reveals that the youths in Abeokuta have interest in the tailoring vocation. The responses of the respondents considered the participatory levels of both male and female youths, it also considered the interest shown by the elderly vis-a-vis the youth tailors in Abeokuta. This study arrives at a result which indicates that the youths in Abeokuta have interest in tailoring vocation. 
This result is in disagreement with the result found in Crowston (2000), Anidugbe (2003) and Khaminwa (2006). The results of the above-mentioned studies indicated a dwindling decrease in the numbers of youths showing interest in professional vocations and artisanship. The reason attributed to this variance in result of studies is inequality in the number of samples taken and also because the studies of Crowston, Anidugbe and Khaminwa were not specific on tailoring per se but on general vocation and artisans

\section{Meeting of Customers Demand and Accurate Specifications}

The responses of the 558 respondents were scored and summed up using frequency counts and the percentage were then calculated as presented below:

Table 3:

\begin{tabular}{|l|l|l|l|l|l|}
\hline & UN & SD & D & A & SA \\
\hline Vb 22 & $45(8.0 \%)$ & $36(6.5 \%)$ & $71(12.7 \%)$ & $174(31.2 \%)$ & $232(41.6 \%)$ \\
\hline Vb23 & $28(5.0 \%)$ & $104(18.6 \%)$ & $152(27.2 \%)$ & $121(21.7 \%)$ & $153(27.4 \%)$ \\
\hline Vb24 & $48(8.6 \%)$ & $77(13.8 \%)$ & $87(15.6 \%)$ & $193(34.6 \%)$ & $153(27.4 \%)$ \\
\hline Vb 25 & $44(7.9 \%)$ & $72(12.9 \%)$ & $100(17.9 \%)$ & $184(33.0 \%)$ & $158(28.3 \%)$ \\
\hline Vb26 & $40(7.1 \%)$ & $45(8.1 \%)$ & $147(26.3 \%)$ & $199(35.7 \%)$ & $127(22.8 \%)$ \\
\hline Vb 27 & $72(12.9 \%)$ & $90(16.1 \%)$ & $129(23.1 \%)$ & $123(22.0 \%)$ & $144(25.8 \%)$ \\
\hline Vb 28 & $47(8.4 \%)$ & $56(10.0 \%)$ & $95(17.0 \%)$ & $105(18.8 \%)$ & $255(45.7 \%)$ \\
\hline Average & $\mathbf{4 6}$ & $\mathbf{6 9}$ & $\mathbf{1 1 2}$ & $\mathbf{1 5 7}$ & $\mathbf{1 7 5}$ \\
\hline
\end{tabular}

Source: Authors' fieldwork, 2016

Key:- UN= Undecided SD = Strongly Disagree D = Disagree A = Agree SA = Strongly Agree Table 3: Customers demands and accurate specifications

\section{Key Parameters}

$\mathrm{Vb} 22$ = Tailors and seamstresses in Abeokuta are old fashioned.

Vb 23 = New fashion styles sells better than old styles.

$\mathrm{Vb} 24=$ Females pay more price to- sew their clothing than the males.

$\mathrm{Vb} 25$ = Tailors in Abeokuta copy fashion styles from foreign catalogues.

$\mathrm{Vb} 26=$ Seamstresses are more conscious than tailors.

$\mathrm{Vb} 27$ = Old fashion styles are more expensive than new fashion stales.

$\mathrm{Vb} 28=$ Clothing in Abeokuta lacks finishing touches.

Table 3 presents the response of samples in Abeokuta as to whether or not tailors meet customers demand in term of styles and time. Out of the total number of 558 respondents, $406(72.8 \%)$ agreed that tailors/seamstresses are old fashioned, 107 (19.2\%) disagreed, while $45(8.0 \%)$ were indifferent. Asked whether the new fashion styles sell better than the old styles, $274(49.1 \%)$ indicated agreement, $256(45.8 \%)$ disagreed, while $28(5.0 \%)$ were undecided in their responses. Question whether female pay more price to sew their clothing than the males, $346(62 \%)$ respondents agreed, while $48(8.6 \%)$ were indifferent. On copying fashion styles from foreign catalogues, $342(61.3 \%)$ agreed that tailors in Abeokuta copy fashion styles from foreign catalogues, $172(30.8 \%)$ disagreed, while 44 (7.9\%) undecided. On the question whether seamstresses are more conscious than tailors in Abeokuta, $326(58 \%)$ agreed that seamstresses are more conscious than tailors in Abeokuta 192 (62\%) disagreed while 40 (7.1\%) were undecided on their response. 411 (47.8\%) respondents agreed that old fashion styles are more expensive than new fashion styles, 219 (39.2\%) disagreed, while 12 $(12.9 \%)$ were indifferent. The issue of finishing touches was addressed, $360(64.5 \%)$ respondents agreed that clothing in Abeokuta lack finishing touches, 151 (27\%) disagree in their response while $47(8.4 \%)$ were undecided. In summary, the data collected reveals that tailors are fond of not meeting customer's demands in terms of styles and time deadlines.

Table 3 indicates the responses collected from the 558 samples on the tailor's habit of meeting customers' demands. The aggregate response shows that tailor fail to meet deadlines in terms of job delivery. It is a common knowledge that every individual must put on cloths either to cover their nakedness or to adorn their bodies or household. This makes tailoring vocation one of the essential trades in the world, and because of the high demand for and patronage of tailors, some collect jobs which they could ordinarily not have been able to finish on time. This result is not an agreement with the conclusion by Hornsby (2001) and Boyer (2009) that trainings of tailors involve rhythm, speed and accuracy. Speed and accuracy in the sense that well-trained tailors get jobs and deliver them well-finished and at the right time. The reason for this disagreement in submission is presumably caused by what one can call "the Nigerian factor". Hornsby's study was earned out in Australia in which case the whites could be said to be conscious of their integrity. The reverse is the case in the Nigeria of 
today.

\section{Hypothesis 1}

The hypothesis states that there is no significant difference in the sewing skill proficiency of male and female tailors in Abeokuta. In testing this hypothesis, the aspect of the instrument that deals with skill acquisition, proficiency and display was addressed, scored and summed up while the obtained mean and standard deviation were then analyzed with t-test statistics. The hypothesis was then tested at 0.05 alpha levels. The result is as presented in table 4 below.

Table 4: t-test of significance of difference between male and female tailors' proficiency

\begin{tabular}{|c|c|c|c|c|}
\hline Variables & $\mathrm{N}$ & $1 \mathrm{C}$ & SD & dft - calt - tab \\
\hline Professional skill proficiency of male tailors & 3.22 & 21.01 & 3.88 & \\
\hline $\begin{array}{l}\text { Professional skill proficiency of female } \\
\text { tailors }\end{array}$ & 2.36 & 21.49 & 3.55 & 1.510 \\
\hline
\end{tabular}

$\mathrm{P}<0.05$ (Significant result)

Table 4 reveals that the mean and the standard deviation for the professional skill proficiency of male were 21.01 and 3.88 respectively while the mean and standard deviation for the professional skill proficiency of female tailors were 21.49 and 3.55 respectively. The table indicates further that the t-calculated value is 1.510 while at df of 556 and with the alpha level of 0.05 , the t-critical value is 1.960. An observation of the tcalculated value and the t-critical value shows that $t$-critical value (1.960) is greater than the $t$-calculated value (1.510). Hence, the hypothesis that says there is no significant difference in the professional skill proficiency exhibited by male and female tailors in Abeokuta is upheld. This is to say that there is no significant difference in the skillful way of both male and female tailors display their professional skill proficiencies in Abeokuta.

The hypothesis 1 that states that there is no significant difference in the sewing skill proficiency of male and female tailors in Abeokuta is upheld. This implies that what a male tailor can do, a female tailor can also do it in terms of sewing skill proficiency. For instance, in the conceptual definition of tailors, seamstresses and fashion designers, Crowtos (2000) and Wikipedia (2008) submit that tailors who are vast in making garments, stitches, sewing and joining can perform the role of a seamstresses while seamstresses too who are vast can display the type of skills that proficient tailors can display. The submissions of Crowston and Wikipedia are absolutely agreement with the results of the hypothesis tested that there is no significant relationship between the sewing skill proficiency of male and female tailors in Abeokuta. The reason for this agreement in results is likely to be because the study of Crowston, although was earned out in Western Cape Coast, sampled 500 respondents in a garment factory including end-users. The study used convenience sampling method to pick samples like the present study.

This hypothesis states that there is no significant relationship between the quality of tailoring facilities and the technical output of tailors in Abeokuta. In testing this hypothesis, the aspect of the questionnaire that addresses quality was scored and summed up for both tailors and end-users. The aspect that addresses technical output was also scored and summed up for each respondent. The two sets of scores were then con-elated using Pearson Product Moment Correlation. The result is as presented in table 4.

Table 5: Test of significance of relationship between quality of tailoring facilities and technical output of tailors

\begin{tabular}{|l|l|l|l|l|}
\hline Variables & N & Df & r - cal & r - tab \\
\hline Quality of tailoring facilities & 558 & & & \\
\hline & & 556 & 0.243 & 0.196 \\
\hline Technical output of tailors & 558 & & & \\
\hline
\end{tabular}

Result significant at $\mathrm{P}<0.05$

Table 5 above reveals that the calculated correlation coefficient ' $r$ ' is 0.243 while at df 558 with the alpha level of 0.05 , the table value is 0.196 . A cursory look at both the $r$-calculated value and the r-table value shows that the r-calculated value $(0.243)$ is greater than the r-table value $(0.196)$ hence the hypothesis that says there is no significant relationship between the quality of tailoring facilities used in Abeokuta and tailors technical output is therefore rejected.

The hypothesis 2 above is tested to know if there is significant relationship between the quality of tailoring facilities and the technical outputs of tailors in Abeokuta. The hypothesis is rejected on the ground that, after testing the study reveals that there is significant relationship between the quality of tailoring facilities and the technical output of tailors in Abeokuta. The result agrees with the findings in Fisher (1844) and reviewed in Forsdyke (2009) which posit that tailors are now exposed to modem use of machines and facilities that makes their outputs perfect and lasting. Forsdyke (2009) submits that quality materials are 
capable of producing quality products and that this feat has elevated the fashion and tailoring outputs to a state remarkable for commercial distinction. The reason for the agreement in the study Forsdyke and this study is that the same sets of facilities were assessed. Even though the environment in which the two studies were carried out are different, Forsdyke correlated between tailoring equipment and the output of the equipment, using the correlation statistics to test the data collected from the client of a U.S. garment industry of the total number of 550. This is a sample that is very close to the 558 samples taken by this study.

Hypothesis 3: There is no significant difference in the interest ofthe youths in tailoring.

Table 6: Test of no significance difference in the interest of the youths in tailoring.

\begin{tabular}{|l|l|l|l|l|l|l|l|l|}
\hline $\begin{array}{l}\text { S/N } \\
\mathbf{o}\end{array}$ & Items & $\begin{array}{l}\text { No of } \\
\text { Response }\end{array}$ & UD & SD & D & A & SA & Total \\
\hline 1. & Youths in Abeokuta have little interest in & 7 & 19 & 38 & 127 & 183 & 184 & 558 \\
\hline & tailoring. & $(93) \cdot$. & $(93)$ & $(93)$ & $(93)$ & $(93)$ & $(93$ & \\
\hline 2. & Tailoring vocation in Abeokuta consists & 7 & 22 & 66 & 124 & 135 & 204 & 558 \\
\hline & of more youths than the elderly. & $(93)$ & $(93)$ & $(93)$ & $(93)$ & $(93)$ & $(93$ & \\
\hline 3. & Interest of the youths of Abeokuta in & 7 & 46 & 106 & 108 & 101 & 190 & 558 \\
\hline & tailoring is decreasing. & $(93)$ & $(93)$ & $(93)$ & $(93)$ & $(93)$ & $(93$ & \\
\hline 4. & Female youths in tailoring are more than & 7 & 50 & 106 & 106 & 100 & 189 & 558 \\
\hline & the males. & $(93)$ & $(93)$ & $(93)$ & $(93)$ & $(93)$ & $(93$ & \\
\hline & TOTAL & $\mathbf{2 8}$ & $\mathbf{1 3 7}$ & $\mathbf{3 1 6}$ & $\mathbf{4 6 5}$ & $\mathbf{5 1 9}$ & $\mathbf{7 6 7}$ & $\mathbf{2 2 3 2}$ \\
\hline
\end{tabular}

Table 6 above showed that the $X^{2}$ "calculated value was 1075.003 while at $\mathrm{df}=15$ and $\mathrm{P}<=0.05$, the table value is 24.996 . Since the $\mathrm{X}^{2}$ calculated value is greater than the $\mathrm{X}^{2}$-table value, the hypothesis that states that there is no significant difference in the interest of youths in tailoring vocation is therefore rejected. In other words, there is significant difference in the interest of the youths of Abeokuta in tailoring vocation.

Table 6 is about the interest of the youths in tailoring. The hypothesis that says that there is no significant difference in the interest of youths in tailoring is rejected. This implies that there is significant difference. It is observed that the youths have not been showing the expected interest in tailoring vocation. Youths are fond of exciting themselves with quick money-yielding pastimes like commercial motorcycle (okada) riding, gambling and taxi driving.

\section{SUMMARY OF FINDINGS}

The field data collected analyzed and discussed in this study presents a result that satisfied both the aim and objectives of the research. The results are hereby summarized below:

i. Although there are both male and female in the tailoring profession, females are not only numerically more than their male counterparts they are also more skilled and creative in sewing styles and fashion designing.

ii. The insinuation of people is that tailoring as a professional practice is not lucrative but this study has proved otherwise. Tailoring is lucrative as its products and the unavoidable nature of its usefulness to every human being cannot be overemphasized.

iii. Tailoring tools and equipment are simple to use, moderate and not heavy to handle and fairly inexpensive compared to equipment in other trades. What negatively affects production or output of tailors is inexperience, unskillfulness, laziness or inability to get appropriate finishing tools for a perfect job.

iv. Interest in tailoring business is painfully decreasing. The youths who are supposed to take over the baton from the older generation show little or no interest on the profession. Most male youths have taken to either commercial motorcycle riding business or other engage in other business that attract quicker income than tailoring. According to the findings of this study, the interest drain does not affect tailoring alone; most other vocations that require apprenticeship training are also affected.

v. Tailors in Abeokuta do not make use of appropriate tailoring tools in the event of doing their work.

vi. One of the challenges that tailor face is their low educational background. This reflects in their productivity and presentation of same. There is need for tailors to be more exposed to literacy as this will keep them in close tune with the goings-with cultural vogues of fashion, styles and tastes 


\section{CONCLUSION}

Skill is important in the practice of tailoring. To be a tailor means that one is either a male or female artisan involved in sewing clothes for men, women and children. The earliest appearance of sewing resided in the quest of man to cover his body and to feel some comfort. Clothing remains ever important for protection, adornment and for fashion. It is apparent that tailors are relevant in the accomplishment of these social valves and it is discovered that not much education is required to foster very well in the trade.

The result of this study reveals that female tailors, despite the fact that they are numerically more than their male counterparts in Abeokuta, they are more skillful, competent and more devoted to work. Notwithstanding, the data gathered and analyzed show that the vocation is lucrative and the quality of machine used by tailors in the town have helped their works so far, In spite of these appraisals, is observed that the present skills and competencies of tailors in Abeokuta may lack sustenance and the trade may suffer continuation as a result of the youths showing decreasing interest in tailoring work. The reason for this is not far-fetched; the youths who could take over the baton of practice from their elders have little or no interest in the vocation and also have wrong notion andpriorities

\section{RECOMMENDATIONS}

The following recommendations are pertinent for better improvement of Tailors/Seamstresses in Abeokuta in order to meet the present day tailoring prevalent styles andtechniques:

1 Tailors/Seamstresses in Abeokuta should be encouraged to make use of modem day sewing machine and other finishing equipment rather than outdated sewing equipment.

2 Tailors/Seamstresses in Abeokuta should have adequate educational background in order to meet present day tailoring demand.

3. The youths in Abeokuta should be encouraged to learn one vocation or the other (such as Tailors) rather than looking for quickest way to make money.

4. Tailors/Seamstresses in Abeokuta should be able to create a prevalent fashion styles rather than copy styles from fashion catalogues.

5. End-users .should be encouraged to patronize tailors/seamstresses in Abeokuta rather than buying already made dresses in the market.

\section{CONTRIBUTIONS TO KNOWLEDGE}

The research has contributed knowledge in that it has provided:

1. adequate and reliable work-plan on service delivery characteristics of tailors and seamstresses as it affects modem fashion trend in Abeokuta, Nigeria; and

2. information that will facilitate skill training and acquisition in tailoring and fashion designing in Abeokuta metropolis.

\section{REFERENCES}

[1]. Abati, R. (2009): The buy-Nigerian-goods all Africa.com. accessed on $16^{\text {th }}$ November, 2010.

[2]. Abe, T.O (2007): Critique of what to and how to do it in project writing, Akure, J.V Educational publishers.

[3]. Aczel, A.D. (1996): Complete Business Statistics $3^{\text {rd }}$ Edition, UK, IRWIN.

[4]. Ajayi, T. (2002): Textile as tools for national development. In Design History in Nigeria, Akinbogun, T. L. (2000): Old wine, new bottles: A cycle of styles in the arts. In Journal of Creative Arts 1, 2.

[5]. Akinlami, O. (1999): The Yoruba cloth weaving Technology and development over time: its prospect in the $21^{\text {st }}$ century. In proceedings of the $21^{\text {st }}$ century convention on Education, Technology and Communication in the $21^{\text {st }}$ century.

[6]. Aluko, O. (1999): Quantitative methods for planning students, Ibadan Kins Book Publishers' series.

[7]. Anidugbe, K. (2003): Professional practice in Visual Art: what it takes to remain in practice. Nigerian artist.

[8]. Arueyinho G.A (2008): Principles and Practice of design for Colleges, Goad publication, Abeokuta.

[9]. Azuma, P. and Femie, J. (2003) Fashion in the globalize world and the role of virtual network's in intrinsic fashion design. In Journal of Fashion Marketing and Management, 3(1).

[10]. Forsdyke, G. (2009): A brief history of sewing macliine.http//www/smarks.Net/sm history.Htm/cited on $14^{\text {th }}$ February, 2009.

[11]. Gilbert R. and Me carter W. (1942): Living with art. New York: Alfred A Knopf Inc.

[12]. Gillow J. (2001): Printed and dyed textiles from Africa, London; Blooms Buiy.

[13]. Hamna, A. A. (2001): Design and Evolution, hr Journal of Industrial Design and Technology 2, 2.

[14]. Hester, S. B. and McDowell, J. E. (1987): Tailoring programs to needs in Journal of Extension. 
[15]. Holy Bible (King James version, 2004: Revised edition Genesis 3: 7).

[16]. Hornby (2001): Oxford Advanced Learner Dictionary of current English, U.S.A Oxford University Press.

[17]. Invention of sewing machine (2008): About.Com. A part of New York times company, cited on $14^{\text {th }}$ March, 2009.

[18]. Israel, G.D. (1992): Sampling the evidence of extension programme impact. Program Evaluation and organizational development, IFAS, University of Florida. PEODS -5.

[19]. Israel, G.D. (2003): Sampling the evidence of extension programme impact. Program Evaluation and organizational development, IFAS, University of Florida. PEODS -5.

[20]. Khaminwa, M. (2010): Nigeria Fashion. An internet document, http://www.africa.comaccessed on 18 November 20016.

[21]. Microsoft Encarta (2008): (c) 1993-2007 Microsoft cooperation, cited on 14 ${ }^{\text {th }}$ March, 2009.

[22]. Microsoft Encarta (2008): Sewing and tailoring. Microsoft Encarta Cooperation, An Internet document, 12 November 2009.

[23]. Negri E. (1976): Nigerian Body Adornment: Nigeria Magazine, Lagos. Nigeria.

[24]. Nworgu, B.G.(1991): Educational research, Basic issues and methodology, Ibadan, Wisdom Publishers Limited.

[25]. Offaiong. A. (2009): Daily trust: An internet document. The online edition cited on $10^{\text {th }}$ February, 2009.

[26]. Ogunduyile, S. R. (1999): Creativity in fashions: its effects on the role of a textile designer in

[27]. the new millennium. In proceedings of the $21^{\text {st }}$ Convention on Education Technology and Communication in the $21^{\text {st }}$ century.

[28]. Ogunduyile, S. R., Kayode, F. and Ojo, B. (2008): Art and Design practice in Nigeria and the

[29]. problem of dropping out. In International Journal of Education and the Arts, 9 4, http;//www.ijea.org, accessed 12 January 2010.

[30]. Oguntona, T. (1998): Prospecting the future of Nigerian textiles. Paper presented at Nigeria

[31]. Global textiles fair, Abuja.

[32]. Oguntuyi, A. (1979): Flistory of Ekiti: Bisi Books Company, Ibadan.

[33]. Ojo, B. (2002): Advancing technology in creativity: A situation report of Design Studio in some selected textiles industries in Nigeria. Perspective on cultural and creativity in Nigeria art. Lagos. Culture and creative forum (CCAF).

[34]. Ojo, B. (1997): Indigenous textile art and technology for rural development. In TET 7, Kaduna. NBTE Publication 1, \& 12, 2, 58-6.

[35]. Ojo, E.B. (2000): Trends in Yoruba Clothing Culture. Journal of Arts and Ideas, O.A.U. Ile-Ife.

[36]. Ojo, E.B. (2001): Boskona: Rags in Costumes Racks. Journal of Creative Arts, UNIPORT, vol. 2.

[37]. Roddy, K (2009): Men's fashion shirts. A free online Articles Dictionary http:

[38]. //www.articlesbase.com/shopping-articles/mens-fashion-shirt $157504 \mathrm{html}$ cited on $3{ }^{\text {ld }}$ December 2010.

[39]. Scribe, D. (2009): Sew home pursuits. An internet document, http://www.sewhomepursuilt.htn accessed on $15^{\text {th }}$ March 2010

[40]. Simelane, X., (2008): Textiles and employee relations in Swaziland. Journal of Employee Relations 30, 4.

[41]. Steel, V. (2002): Clothing Microsoft (R) Encarta (R) online Encyclopedia. Cited on $15^{\text {th }}$ June, 2009.

[42]. Swindells, S, Atkinson, P, and Sibley (2001): The professional with art design and Architecture Practice and Education. IDATER, Conference proceeding on Art Design and Architecture Practice, UK , Southborough University.

[43]. Trautman, P. (2006): An eighteenth-century American tailor; myth and reality, as seen through one tailor surviving records in clothing and Textile Research Journal.

[44]. Uzoagulu A.E. (1998): Practical guide to writing. Research project reports in Tertiary Institution, Nigeria, John Jacobs Classic publishers.

[45]. Wales, J. (2009): Tailors: http//enwikipedia org./wiki/tailor, cited on $15^{\text {th }}$ June 2009.

[46]. Wikipedia Encyclopedia (2009): Fashion design. An internet document http://www.en. wikipedia.org/wiki/fashion design. Accessed 6 October, 2016. Wikipedia Foundations, Inc.

[47]. Wikipedia the free encyclopedia (2008): http:/en.wikipedia.org./wiki/fashion design, assessed on $14^{\text {th }}$ March, 2016 